Commentary

\title{
Authoritarian Norms in a Changing International System
}

\author{
Thomas Ambrosio \\ Department of Criminal Justice and Political Science, North Dakota State University, Fargo, ND 58103, USA; \\ E-Mail: thomas.ambrosio@ndsu.edu
}

Submitted: 13 March 2018 | Accepted: 19 March 2018 | Published: 22 June 2018

\begin{abstract}
The normative structure of the international system is changing, driven by the logics of effectiveness and appropriateness. Whereas the balance between democracy and autocracy had clearly favored the former, this appears to no longer be the case. Not only are authoritarian methods spreading because they have been found to be successful, but democracy's very legitimacy has been eroded from self-doubt and as a consequence of rising and increasingly confident authoritarian great powers. This commentary provides an overview of these trends.
\end{abstract}

\section{Keywords}

authoritarianism; China; democracy; diffusion; Russia

Issue

This commentary is part of the issue "Authoritarianism in the 21st Century", edited by Natasha Ezrow (University of Essex, UK).

(C) 2018 by the author; licensee Cogitatio (Lisbon, Portugal). This article is licensed under a Creative Commons Attribution 4.0 International License (CC BY).

\section{Introduction}

The international system is currently going through a profound transition. The balance between democracy and autocracy, which seemed tilted so far to the former's advantage during the 1990s and the mid-2000s, appears to be leveling out, with ever more assertive authoritarian states and an increasingly embattled democratic world. One only need look at the headlines.

In March 2014, Russia annexed the Crimean peninsula from Ukraine in a clear act of aggression, violating one of the most sacred post-Second World War European norms prohibiting territorial aggrandizement. Although few countries recognized its legality, nearly everyone has adjusted to this new reality. Russia has also fueled a civil war in eastern Ukraine, which brought sanctions, but little else. 18 months later, Russia intervened militarily in Syria, representing the first time since the end of the Cold War that a great power used force outside of its immediate neighborhood in defiance of American wishes. Russia is now seen as a player in the Middle East, a region from which it largely had been expelled decades before.

An expanding China is seizing islands in the South China Sea, hundreds of miles away from its mainland and in the territorial seas of several Asian countries. The Permanent Court of Arbitration's 2016 ruling against these moves was shrugged off by Beijing as barely a distraction. In the summer of 2017, China's first, official overseas military base was opened in Djibouti, marking China's expansion into the Middle East and Africa. This solidifies the fact that China is now more than just a regional actor and imbues that country with the trappings of the rising power of the future.

Even in the democratic West, there are mounting questions about the strength of liberal norms as populism continues to spread at the ballot box. Certain countries once thought to be the paragons of a postcommunist transition, such as Hungary and Poland, have seemingly copied from the playbook which had previously led to the creation of authoritarian regimes in Belarus and Russia. Moreover, Turkey, a NATO member and perennial European Union hopeful, continued its steady shift from democracy to autocracy-a process which seems both unstoppable and, by now, all too familiar. Freedom House's 2011 Freedom in the World report (Freedom House, 2011) was entitled The Authoritarian Challenge to Democracy. It was updated in 2018 as Democracy in Crisis (Freedom House, 2018). A new ideological normal appears to be descending on the world. 
The swan song of democracy's recent dominance was likely the Color Revolutions. While they were initially successful, they taught autocrats valuable lessons which forestalled what some believed would be the beginning of a "fourth wave" of democracy. The so-called Arab Spring of 2011 rapidly turned into an Arab Winter, with regimes either descending into chaos or strengthening their dictatorships. Only Tunisia benefitted from this optimistic, but ultimately premature, moniker.

The norms that operate within the international system cannot help but be affected by this upsurge of authoritarianism. This wider environment fosters the creation of new norms, weakens or strengthens those that already exist in line with these changes, and facilitates their spread from one country to another. New policies at the domestic level are inevitable as the context within which policies are made has now changed.

This process is driven by two logics: effectiveness and appropriateness (Ambrosio, 2010). The former makes it more likely that norms and the policies shaped by them will be adopted because they appear to be successful. The current autocratic moment was initially driven by this logic. As authoritarian regimes learned lessons from the successes and failures of others, they developed a collection of policies and institutional changes to make them better able to resist democratic pressures at home and from abroad. This has become alternatively called "political technology" (Wilson, 2005), an "authoritarian toolkit" (Diamond, Plattner, \& Walker, 2016), or a "menu of manipulation" (Schedler, 2002). Through the logic of effectiveness, items in this tried and tested list were copied by others with the purpose of eroding democracy and strengthening dictatorship. There is no single origin of this methodology, but the "Putin model" is perhaps the most prominent variety within the European context and includes several steps such as weakening the judiciary, undermining nongovernment organizations and civil society, centralizing power, controlling the media, manipulating the electoral process, and selective repression. All of this serves to create a façade of democracy. We can see its influence even in countries once thought to be consolidated democracies, such as Fidesz's systematic attack on checks and balances in the Hungarian political system. Although not always successful, as Viktor Yanukovych found to his misfortune in Ukraine, this blueprint became ubiquitous for the simple reason that it works.

We now appear to be entering a new stage of the global normative structure where the logic of appropriateness increasingly applies. This logic rests, not upon the success of norms or policies, but upon their very legitimacy. According to the diffusion literature, this is the difference between learning (effectiveness) and emulation (appropriateness). In cases of emulation, the normative environment creates pressures to conform to a course of action because it is seen as right and proper. Deviation from this is constrained by the need "to signal...commitment to global norms" (Simmons, Dobbin, \&
Garrett, 2006, p. 799). When the legitimacy of the old norms weaken, it is easier to violate them and to adopt new ones.

One can see how this once worked in democracy's favor. Within post-communist Europe, communism was not only proven to be a failure, but democracy came to be seen as the only legitimate form of government in the region. Globally, a unipolar international system centered on a norm-proselytizing United States engendered conditions which led McFaul (2010) to title an article "Democracy Promotion as a World Value". The "Asian values" resistance to liberalism during the 1990s never achieved enough normative legitimacy to substantively erode the propriety of democracy. Even Putin framed his power grab in terms of democracy-"sovereign democracy," granted, but democracy nonetheless. Although liberal democracy was never truly the only game in town, a key factor maintaining the global balance in its favor was the widespread belief in democracy's dominant claim to legitimacy. The fact that autocratic regimes paid lip service to the forms of democracy was indicative of its normative power.

As the global legitimacy of democracy appears to be eroding, it is quite possible that a sea change is either currently happening or is on the horizon. If we regard of this as a normative tug-of-war between democracy and authoritarian, then as one weakens, the other strengthens.

Part of this is due to the internal situation within the democratic West which currently expresses itself through the outpouring of populist sentiments. Examples abound. Consider just the following: the rise of populist parties throughout Europe, including and the Alternative for Deutschland, and their electoral victories Hungary, Austria, Poland; the Brexit vote, which succeeded over the objections of all of Britain's major parties; Donald Trump's presidency in America; and, the fact that the center-left and center-right establishment parties are receiving their lowest vote totals since the Second World War in countries such as France, Germany, and Italy. To paraphrase one of the most over-quoted poems in Western civilization, the center, clearly, is not holding. This is obviously due, to a large extent, to concerns about immigration and the fallout from the Great Recession. However, it seems far deeper than this. There is a crisis of confidence within the democratic world, not just about the performance of its institutions, but one which questions the very foundations of the neoliberal consensus. The fact that Viktor Orbán (2014), the prime minister of a European Union member state, can criticize the very foundations of liberal democracy and openly declare that he supports building an "illiberal state", citing such countries as "Singapore, China...Russia, Turkey" as his role models, is indicative of how dramatically things have changed. If the democratic West is questioning itself so at such a basic level, then why shouldn't others? This cannot but help to shift things more in favor of authoritarianism.

Within the authoritarian world, autocrats are becoming more confident and their authoritarian policies more 
overt and brazen. Whether this means removing term limits to that they can potentially rule for life, openly interfering in democratic elections in the West, violently cracking down on peaceful protestors, or creating a dynasty by grooming their children to govern after they are gone, the mask has clearly slipped and autocrats are now far less concerned about keeping up the pretenses of democracy. To put it in terms of emulation, governments feel far less concerned about deviating from democratic norms. As such actions become routine, this creates a normative feedback loop which normalizes authoritarianism and reinforces the logic of appropriateness.

That this is occurring even in the absence of proselytizing states is notable. Chinese President Xi Jinping (2015) said that "we have no intention to interfere in other countries' internal affairs, export our own social system and model of development, or impose our own will on others". And there is a lot of truth to this, as modern-day China is clearly no Maoist regime, seeking to spread its version of communism. Putin's Russia, too, is definitely no Soviet Union, which consistently presented itself as a role model to the rest of the world. The fact that neither currently possesses a missionary impulse is ultimately irrelevant, however. While the respectability of norms is strengthened by practice, it is also bolstered by the prestige of major powers which "effectively define international standards of legitimacy, serving as models for other states" (Fordham \& Asal, 2007, p. 32). One analysis referred to this as "authoritarian gravity centres" (Kneuer \& Demmelhuber, 2016, p. 3). Russia's increased standing on the global stage is surpassed only by China's, which has emerged as the second most powerful country in the world. Even if there is no intention of advancing an ideological agenda, these powerful authoritarian states will inevitably change the nature of the global debate between democracy and autocracy. As more states go down this path, this creates a de facto 'reference group', which further makes authoritarianism appear appropriate. One can cite as evidence of this process the Shanghai Cooperation Organization's role in legitimizing regional norms against regime change and effectively fortifying Central Asian authoritarianism.

In short, the normative structure of the international system is changing. The democratic world must prepare itself for a new, new world order in which the balance between democracy and autocracy no longer clearly favors itself.

\section{Conflict of Interests}

The author declares no conflict of interests.

\section{References}

Ambrosio, T. (2010). Constructing a framework of authoritarian diffusion: Concepts, dynamics, and future research. International Studies Quarterly, 11(4), 375-392.

Diamond, L., Plattner, M., \& Walker, C. (2016). Authoritarianism goes global: The challenge to democracy. Baltimore, MD: Johns Hopkins University Press.

Fordham, B., \& Asal, V. (2007). Billiard balls or snowflakes? Major power prestige and the international diffusion of institutions and practices. International Studies Quarterly, 51(1), 31-52.

Freedom House. (2011). Freedom in the world 2011: The authoritarian challenge to democracy. Retrieved from https://freedomhouse.org/article/freedomworld-2011-authoritarian-challenge-democracy

Freedom House. (2018). Freedom in the world 2018: Democracy in crisis. Retrieved from https://freedom house.org/sites/default/files/01042018_FINAL_Press Release_FIW2018.pdf

Kneuer, M., \& Demmelhuber, T. (2016). Gravity centres of authoritarian rule: A conceptual approach. Democratization, 23(5), 1-22.

McFaul, M. (2010). Democracy promotion as a world value. Washington Quarterly, 28(1), 147-163.

Orbán, V. (2014). A munkaalapú állam korszaka következik [We are facing the era of a state based on work]. Website of the Hungarian Government. Retrieved from http://www.kormany.hu/hu/a-miniszterelnok/ beszedek-publikaciok-interjuk/a-munkaalapu-allamkorszaka-kovetkezik

Schedler, A. (2002). The menu of manipulation. Journal of Democracy, 13(2), 36-50.

Simmons, B., Dobbin, F., \& Garrett, G. (2006). The international diffusion of liberalism. International Organization, 60(4), 781-810.

Wilson, A. (2005). Virtual politics: Faking democracy in the post-soviet world. Cambridge, MA: Yale University Press.

Xi, J. (2015). Full text of President Xi's speech at opening of belt and road forum. Ministry of the Foreign Affairs of the People's Republic of China. Retrieved from http://www.fmprc.gov.cn/mfa_eng/wjdt_665385/zy jh_665391/t1465819.shtml 


\section{About the Author}

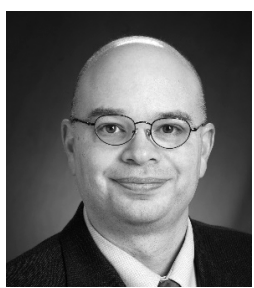

Thomas Ambrosio is a Professor of Political Science at North Dakota State University in Fargo, North Dakota (United States). He has published three books and edited two volumes, as well as numerous articles and book chapters. His main areas of research include authoritarianism, Russian foreign policy, and American threat perceptions. His most recent research projects include the geopolitics of Barack Obama's State of the Union addresses, authoritarian learning, American threat perceptions of Russia, Russia's rhetoric surrounding the annexation of Crimea, and Russia's treaty networks with China, Abkhazia, and South Ossetia. He is currently working on a project investigating hereditary grooming in the former Soviet Union. 